Szabó Éval - Litke Márta ${ }^{2}$ - Jagodics Balázos ${ }^{3}$

1 SZTE-BTK Pszichológiai Intézet

2 Győr-Moson-Sopron Megyei Pedagógiai Szakszolgálat Győri Tagintézménye

3 SZTE-BTK Pszichológiai Intézet

\title{
Az óvodapedagógusok kiégésének vizsgálata a munkaértékek tükrében
}

A kiégés fogalmának megjelenése az 1970-es évekre tehetó, amikor a nyugati társadalmakban létrejövó viszonylagos jólét folyamatos pályaelhagyási és így foglalkoztatási válságot generált. A szakirodalomban való megjelenése Freudenberger (1974) nevéhez köthetó, aki azon pszichés állapot leírására alkalmazta a fogalmat, amelyet az egyén lelki és fizikai eróforrásainak kimerülése jellemez. „A kiégés-szindróma krónikus, emocionális megterhelések, stresszek

nyomán fellépó fizikai, emocionális, mentális kimerülés állapota, amely a reménytelenség és inkompetencia érzésével, célok és ideálok elvesztésével jár, s amelyet a saját személyre, munkára, illetve másokra vonatkozó negatív attitúdök jellemeznek." (Fekete, 1991, 17.).

\section{A kiégés fogalma és jellemzői}

A kezdeti időszakban a kutatások célja a jelenség meghatározása és leírása volt. A korai vizsgálatok alapján Freudenberger (1980), Appelbaum (1981) és Pines (1992) eredményei is jelezték a munkahelyi stressz és az abból fakadó kiégés-szindróma közötti összefüggést (Kollár, 2014). Maslach (1982) a kiégés-szindrómát a krónikus érzelmi és interperszonális stressz folyamatokra adott válaszreakcióként definiálta, és a tünetek három dimenzióját különítette el: az érzelmi kimerülés állapotát, az elszemélytelenedést és a csökkent teljesítmény, inkompetencia érzését. Maslach és Schaufeli (1993) szerint a nagy érzelmi munkát igénylő foglalkozást végzők a leginkább veszélyeztettetek. Így a kiégés tekintetében kiemelt rizikófaktorba sorolhatók a segítő munkakörben, oktatásban tevékenykedők, illetve az egészségügyi dolgozók, akik nap, mint nap betegekkel, gyakran haldoklókkal foglalkoznak (Pruyser, 1984). A stressz, a társas konfliktusok és a nagymértékü munkahelyi terhelés sok esetben elörevetítik a kiégés bekövetkezését így a munkahelyi és személyiségi tényezők együttesen játszanak szerepet a kiégésben (Zapf, 2002).

Hare, Pratt és Andrews (1988) a kiégésért felelős tényezőket három csoportba sorolta: szituációs (demográfiai jellemzők és a munkavégzés sajátosságai), interperszonális- (társas támogatás észlelt értéke) valamint az intraperszonális (egyénre jellemző megküzdési stratégiák) jellemzők. A demográfiai jellemzők vizsgálata tekintetében Maslach és munkatársai (2001) arra a megállapításra jutottak, hogy a fiatalok veszélyeztetettebbek, mint a régóta pályán lévők. Ezt az összefüggést a hazai kutatások is megerősítették (Gáspár és mtsai, 2006). A pedagógusok körében a pályaelhagyás is 20 és 40 éves kor között a legmagasabb (Kocsis, 2003). Később a Koruklu és munkatársai (2012) által végzett kutatás rávilágított arra az összefüggésre is, hogy a 20 és 40 év közötti tanárok túlnyomórészt 
az érzelmi kimerülés és elszemélytelenedés tekintetében észlelnek tüneteket, míg az idősebb korosztály a személyes teljesítmény csökkenésében tapasztalja a kiégés-szindrómát.

A nemzetközi trendhez képest hazánkban kevesebb kutatás kapcsolódik a kiégéshez, számuk azonban egyre inkább növekszik. Elsősorban az egészségügyi dolgozókat, leginkább az orvosok (Ádám és mtsai, 2006, 2008, 2009; Győrffy és Ádám, 2004; Hegedüs, 2000; Bognár és mtsai, 2001) és az ápolók, nővérek csoportjainak kiégését vizsgálták (Pikó, 2001,2006; Kovács, 2006; Szicsek, 2004; Hegedüs és mtsai, 2004; Pálfi, 2003). A másik leginkább kutatott pálya a pedagógusoké, azon belül is a tanítóké, tanároké (Petróczi és mtsai, 1999, Ónody, 2001, Paksi és mtsai, 2015, Jagodics és Szabó, 2016).

\section{Kiégés és a pedagógus pálya}

A humán szférában dolgozó nevelést, oktatást végző pedagógusok, andragógusok lelki egészsége kiemelten veszélyeztetett, hiszen nagy nyomás nehezedik rájuk a társadalom részéröl a hibátlan munkavégzés tekintetében. A gyermekekkel és a szüleikkel való foglalkozás elkerülhetetlenül vonzza az erős érzelmi bevonódást. Idealizált elvárásoknak kell megfelelniük, úgy, mint az állandó jókedv, biztonságteremtés és a magas intelligencia. Ezzel párhuzamosan ritkák a munkájukra vonatkozó visszajelzések és sok esetben kevés a sikerélményük (Bagdy, 1994). Paksi és munkatársainak a hazai pedagógusok pályamotivációját és lelki egészségét feltáró kutatási eredményei (2015) rávilágítottak arra is, hogy a pedagógushivatás társadalomi és anyagi megbecsültsége is jócskán elmarad más értelmiségi pályákétól. A pálya előnyének tartják azonban a munka-magánélet egyensúly könynyebb megteremtését, illetve az önmegvalósítás lehetőségét. Vizsgálatuk alapján a hazai tanárok 5-8\%-a szenved a kiégés tüneteitől, míg a nemzetközi vizsgálatokban ennél jóval magasabb, 25\%-os értéket találtak (Barth, 2012). Ez a diszkrepancia számos elméleti és módszertani kérdést vet fel, valamint ellentmond a pedagógusokkal kapcsolatos általános tapasztalatoknak is. A pedagógusok jellemzően túlterheltek, munkájuk során számos szerepkonfliktussal kell szembe nézniük, a rendelkezésre álló eszközök mennyisége és minősége nem megfelelö és gyakran a negatív munkahelyi klíma is táptalaja az interperszonális konfliktusoknak. Egy finn mintán végzett vizsgálat szerint, a humán szférán belül a tanári pályán volt leginkább tetten érhető a kiégés, amit elsősorban a beszédstílusban megnyilvánuló cinizmusban lehetett kimutatni (Hakanen, Bakker és Schaufeli, 2006).

Bár a kiégésben kétségkívül fontos szerepet játszanak egyéni tényezők, a kutatások mégis arra utalnak, hogy a jelenség elsősorban a munkahelyi stresszhez köthetö (Maslach és Jackson (1981). A környezeti tényezők hatását feltáró kutatások három főbb területen lehet tetten érni: úgy, mint a munka sajátosságai, a foglalkozás specifikumai, valamint a szervezet jellegzetességei (Maslach és mtsai, 2001).

\section{A kiégés és a munkaértékek kapcsolata az óvodapedagógusok tekintetében}

Az egyén munkával és élettel való elégedettsége nagymértékben függ attól, hogy képességeinek, érdeklődési körének, személyiségjellemzőinek és értékítéleteinek hasznosítására milyen lehetőségek kínálkoznak az adott munkaterületen (Duró, 2005). A segítő hivatások, ahogy a kisgyermeknevelés is, magában hordozzák a kiégés veszélyét, de ezt ellensúlyozhatja, a munka különböző dimenzióihoz (pl pályaválasztáshoz) kapcsolódó elégedettség. Igy, a kiégés megelőzésében fontos szerepe lehet a pályaválasztást motiváló munkaértékek feltárásának, tisztázásának is (Gáspár, 2008). Az aktív pedagógusok értékelvárásainak mintázata nyomán képet alkothatunk arról, mely értékek jellemzik a szakma sikeres, elégedett tagjait (Holecz, 2015; Fónai, Zolnai és Kiss, 2005). vagy megfordítva, ezek hiányából következtethetünk a kiégés veszélyeztettségre. 
A munkahelyi feltételeket és a segítők hivatásukkal, önmagukkal kapcsolatos attitüdjét vizsgálva láthatjuk, hogy a kiégés pozitív korrelációt mutat a képzettség fokával, az önkiteljesedés vágyával és az ezzel kapcsolatos nagyfokú szakmai elvárásokkal, illetve a pályán eltöltött idővel (Pines és Maslach, 1978). A kutatók úgy találták, hogy akik nagy lelkesedéssel, túlzott idealizmussal kezdték meg pályájukat, gyakran már a munkavégzés első évei alatt komolyan veszélyeztetettek kiégés szempontjából (Hézser, 1996). A segítő szakemberek túlterheltsége, privát és szakmai életük összemosódása, a reményvesztettség állapota gyakran a képzett munkaerő pályaelhagyásához vezet (Fekete, 1991).

\section{Problémafelvetés}

$\mathrm{Az}$ áttekintett szakirodalmakból is látszik, hogy a pedagógusok kiégésével kapcsolatos vizsgálatok fókuszában többnyire kifejezetten csak a tanári pálya áll. A hasonló nevelői munkát végző óvodai nevelök vizsgálata kevésbé vagy egyáltalán nem merült fel. A kisgyermekneveléssel kapcsolatos tanulmányok, cikkek leginkább a gyermeknevelésre, fejlesztésre koncentrálnak, a neveló személyére, mentálhigiénés állapotára kevésbé térnek ki. Úgy véljük, hogy a pálya jellegzetességei miatt, a kiégés jelensége az óvodai nevelőket is érinti.

A hazai viszonyokra speciálisan jellemző, hogy az óvodáknak is alkalmazkodniuk kell a 80-as évektől nyomon követhetö társadalmi változásokhoz, amelyek a családok életében is megmutatkoznak. A nevelöi munka szempontjából nagy kihívást jelent az egymástól eltérő értékrenddel, sokszor súlyos családi terhekkel érkező gyermekek szocializációjának segítése. Gyakori a tehetetlenségérzés, az időnyomás, a szülőkkel való kapcsolattartás, a fegyelmezés problematikája, amelyek mind további stresszornak számítanak az óvónők munkájában (Kyriacau, 2001, idézi: Torma, 2013). Mindezek alapján indokoltnak látjuk, hogy a pedagógusok e speciális csoportját is beemeljük a hazai kiégéssel kapcsolatos vizsgálatok sorába.
Az óvodapedagógusok munkájára is jellemzó a fokozott men-

tális terhelés, amely többek között a mindennapi foglalkozásokra való készülésben, az azokon való részvételben és az ahhoz szükséges folyamatos figyelemben, készenlétben nyilvánul meg (Demerouti és mtsai, 2001). A kiégés elófordulása szintén összefügghet a csoportok létszámával és a felkészüléshez szükséges idôvel (Lackritz, 2004). Tovább fokozhatja a pedagógusok terhét, ha homogén életkori csoport helyett vegyes csoportban dolgoznak, ahol különbözó életkorú gyerekekkel kell egyszerre helytállniuk. Az óvodákban gyakran nem megfeleló a foglalkozásokhoz, játékhoz szükséges eszközök minósége vagy akár éppen ezek hiánya is tapasztalható, amely szintén fokozza a túlterheltséget (Fernet és mtsai, 2012). Az intézményben érvényesüló bürokrácia, az admi-

nisztrációs túlterheltség (Candová, 2005), a nem egyértelmú, egymásnak gyakran ellentmondó feladatok és célok. (Simbula és mtsai, 2012), a fele-

lósségek és jogosultságok, az autonómia hiánya vagy határainak elmosódottsága (Bracci, 2009) is gyakran szerepel a kiégés lehetséges okaként, vagy befolyásoló tényezóként. 


\section{Célkitüzések és hipotézisek}

Kutatásunk célkitüzése elsősorban az volt, hogy képet kapjunk az óvodapedagógusok vizsgált mintájának a kiégettségéröl, és annak jellemzőiről. Másrészt arra a kérdésre kerestünk választ, hogy a munkahelyen tapasztalt munkaértékek hogyan kapcsolódnak a kiégéshez. melyek azok a munkaértékek, amelyek alacsony színvonalú megvalósulása legerősebben összefügg a kiégés jelenségével. Jóllehet munkánk elsősorban feltáró jellegü, de a kiégéssel kapcsolatos korábbi kutatások alapján megfogalmaztunk néhány hipotézist

H1: Feltételeztük, hogy a pályán eltöltött idö és a kiégésfogékonyság között pozitív kapcsolat van (Maslach és mtsai, 2001; Koruklu és mtsai, 2012).

H2: A vegyes csoportban dolgozó óvónők magasabb kiégés fogékonyságot mutatnak, mint a homogén életkori csoportban dolgozók, mivel az őket érő terhelés nagyobb és sokoldalúbb (Fernet és mtsai, 2012)

H3: A munkahellyel és a hivatással kapcsolatos elköteleződés összefügg a kiégéssel. Az elkötelezettebb csoportokban alacsonyabb kiégés értéket kapunk (Pines és Maslach, 1978).

A munkaértékek és a kiégés kapcsolatát eddig még nem vizsgálták, így ezzel kapcsolatban nem fogalmaztunk meg konkrét hipotéziseket. Kérdésként tettük fel, hogy vajon mely munkaértékek azok, amelyeket legerősebben megélnek a pedagógusok, és melyek azok, amelyeket a legkevésbé, valamint, hogy a megtapasztalt munkaértékek, illetve azok hiánya hogyan kapcsolódik a kiégéshez.

\section{Módszerek}

\section{Kiégés-kérdőív}

Az óvónők kiégés fogékonyságát a Maslach-féle kiégés kérdőív tanári munkára specializált változatából (Hennig és Keller, 1995) Jagodics és Szabó (2016) által kialakított mérőeszközzel mértük, amelynek statisztikai megbízhatóságát korábbi kutatásokkal ellenőriztük. A kérdőív három alskálából áll, amelyek négy-négy tételből épülnek fel. A három alskála: a kiégés lelki, érzelmi és társas tüneteit méri. A válaszadás 0-4-ig terjedő Likert-skálán történt. Az alskálák mindegyikén maximálisan 16 pont érhető el. Az összesített pontszám a kiégés-stressz fogékonyságmutató, maximális értéke 48 pont lehet. A kérdőív belső konzisztenciája mintán is jónak tekinthető $(\alpha=0,784)$, így az elemzésben a korábban publikált kérdőív struktúrát használtuk.

\section{Super-féle munkaérték kérdőív}

A pályakép és értékorientáció vizsgálatára a Super-féle munkaérték kérdőívet alkalmaztuk. Az önkitöltős kérdőívét Super először 1968-ban közölte. A kérdöív 15 értékkört és 45 tényezőt tartalmaz. A kérdőív hazai adaptációja Csepeli és Somlai, 1978, valamint Fónai és mtsai, 2005 nevéhez füződik. A módszer széles körben használt elsősorban a pályaalkalmassági vizsgálatok és a szervezetfejlesztés területén. A Super-féle életút teória a magyar kutatók közül többek között Csirszka (1966), Rókusfalvy (1969), Ritoók (1986) és Völgyesi (1976) vizsgálataiban is megjelenik, majd az őket követő kutatói generáció (pl. Herskovits, Xantus, Szilágyi, Rajnai, Schüttler) is átvette ezt a szemléletet (Fónai, Zolnai és Kiss, 2005). 
A méröeszköz az alábbi 15 értékkört vizsgálja:

1. Szellemi ösztönzés: olyan munkához kapcsolható értékkör, amely lehetővé teszi a független gondolkodást és a dolgok alakulásának megismerését (pl. „szüntelenül új megoldatlan problémákba ütközik").

2. A munkateljesítmény: a teljesítmény megélése a munkavégzésben, mely megmutatkozik a feladatra való orientációban és a látható eredményeket hozó munka preferálásában (pl. „objektíven lemérheti munkája eredményét”).

3. Az önérvényesítés: az életmódra vonatkozó érték, mely olyan típusú munkával kapcsolatos, amely lehetővé teszi az egyéni elképzelések érvényesülését az életforma és az életmód megválasztásában (pl. „megvalósíthatja önmagát”).

4. Az anyagi ellenszolgáltatás: ez az érték olyan munkára vonatkozik, amely jól fizet és lehetőséget ad az egyén számára fontos dolgok, tárgyak birtoklására és megszerzésére (pl. „sok pénzt kereshet”).

5. Az altruizmus: a szociális kapcsolatokban megnyilvánuló érték, olyan munkára utal, amelyben mód nyílik mások boldogulásának előmozdítására (pl. „másokon segíthet”).

6. Kreativitás: ez az érték olyan munkajellemzőkre utal, amelynek során mód nyílik új dolgok bevezetésére, új termékek tervezésére, vagy új elméletek alkotására (pl. „új elképzeléseket alakíthat ki").

7. Társas kapcsolatok: ez az érték arra a munkára jellemző, amelyet jó munkahelyi légkörben végez a személy, jó munkahelyi kapcsolatban él (pl. ,jól kijön munkatársaival").

8. A munkával kapcsolatos biztonság: ez az értékkör a munkaerőpiacon való versenyképesség érzetéről, fontosságáról szól (pl. „biztos elhelyezkedés”).

9. Presztízs: ez az értékkör mások elismerése iránti igényre utal. Ez nem feltétlenül a hatalom iránti vágyat jelenti, bár a tisztelet nagyon gyakran a státuszhoz is kapcsolódik (pl. „biztos lehet abban, hogy munkájáért a többiek megbecsülik”).

10. Irányítás (vezetés): vezetési igényekre vonatkozó értékkör, amely olyan munkával kapcsolatos, ahol lehetőség van mások munkájának megtervezésére, munkafeltételek megteremtésére, munkaszervezésre (pl. „mások munkáját is irányíthatja”).

11. Változatosság: a munkatevékenységgel kapcsolatban az élvezetet és az örömkeresést jelenti a feladatorientációval szemben, amelynek relatív fontossága függ az egyén lelki alkatától, a szubkultúrától és a körülményektől (pl. „változatos munkát végezhet").

12. Esztétikum: mint érték, olyan munkában rejlik, amely lehetővé teszi szép dolgok, tárgyak készítését, és hozzásegít a világ szebbé tételéhez (pl. „szépet teremthet”).

13. Függetlenség: olyan munkával kapcsolatos, amelynek során lehetöség van arra, hogy az egyén saját elképzelései, és módszere szerint dolgozhasson ( $\mathrm{pl}$. „szabadon dönthet saját területén").

14. Hierarchia/felügyeleti viszonyok: az igazságos ellenőrzés alatt végezhető munkával kapcsolatos értékkör, amelyben a munka értékelésére való igény, és a fönökökkel való összeférhetőség igénye fogalmazódik meg (pl. „megértő vezetője van”).

15. Fizikai környezet: a kényelmes, rendezett fizikai környezet iránti igény, annak munkavégzésben való fontosságának érzete fogalmazódik meg benne (pl. „,szép környezetben dolgozhat").

Kutatásunkban a kérdőívet rendhagyó módon használtuk. Kérdésünk nem az értékpreferenciákra vonatkozott, hanem arra, hogy az adott munkaérték mennyire jellemzö szerinte a munkahelyén. Így nem a vágyott, hanem a megélt munkaértékekről kapunk információt. 


\section{Vizsgálati eljárás}

Kutatásunkban online, anonim kérdőíves vizsgálat módszerével dolgoztunk. A kérdőív három részből állt. Az első részben az un. demográfiai adatok kerültek felvételre, a második részben a munkaértékek majd pedig a kiégés vizsgálata történt. A kérdőív kitöltése önkéntes volt. A demográfiai adatok között rákérdeztünk a nemre, életkorra, családi helyzetre, a pályán eltöltött idöre, a munkahely főbb jellemzőire, valamint a pályaelhagyással kapcsolatos gondolatok gyakoriságára és a hivatással kapcsolatos elköteleződésre is.

A vizsgálati személyek toborzása hólabda módszerrel történt. A célzott mintavétel érdekében óvodapedagógusok közösségi oldalára tettük fel a felhívást és a kérdöív linkjét. A kérdőív elején írásos tájékoztató szerepelt a vizsgálat céljáról, az adatok etikus kezeléséről. A kérdőív kitöltésével a személyek beleegyeztek a vizsgálatban való részvételbe, melyért ellenszolgáltatást nem kaptak. Az adatok feldolgozása SPSS Statistics Version 23 program segítségével történt.

\section{Eredmények}

\section{A minta demográfiai jellemzői és munkával, hivatással való elkötelezettsége}

A kutatásban 109 fö vett részt, ebből összesen egy fö volt férfi. Így a továbbiakban nemenkénti összevetést nem végeztünk. A kitöltők átlagéletkora 43,2 év ( $S D=10,9$ év). A legfiatalabb résztvevő 22, míg a legidősebb 61 éves volt. A résztvevők átlagosan 19,6 éve dolgoznak a pályán (SD=13,1 é. A kitöltők között a legkevesebb óvodapedagógusként eltöltött idő 1 év, a legtöbb 42 év volt. A válaszadók közül 65 fö (59,6\%) vegyes csoportban, míg 44 fö $(40,4 \%)$ homogén életkori csoportban dolgozik.

A pályával kapcsolatos elkötelezettség vizsgálata két kérdés segítségével történt. Az egyik a pálya újraválasztására, a másik a pálya elhagyással kapcsolatos gondolatok gyakoriságára kérdezett rá. Az általunk vizsgált csoportban a résztvevők több, mint fele elkötelezett a hivatásával kapcsolatban (1.ábra). Ha ismét lehetősége lenne pályát választani, biztosan az óvodapedagógus pályát választaná a kérdezettek $61 \%$-a. A pálya elhagyásán a kérdezettek 17,4\% gyakran, 43,1\%-a ritkán gondolkodik és 39,4\%-nak ez nem szokott eszébe jutni.

\section{A kiégés fogékonyság jellemzői és kapcsolata a pályán eltöltött idővel és a vezetett csoportok jellemzőivel}

A teljes minta adatait figyelembe véve $(\mathrm{N}=109)$ a kiégés-kérdöív három alskálája közül az érzelmi kiégés pontszáma volt legmagasabb $(\mathrm{M}=5,87 ; \mathrm{SD}=3)$, melyet a lelki $(\mathrm{M}=4,53$; $\mathrm{SD}=2,49)$ és a társas $(\mathrm{M}=2,73$, szórás $=2,41)$ területek követtek. A három terület együttes eredményeit jelző összesített kiégés pontszám átlaga $13,15(\mathrm{SD}=6,49)$ pont volt a lehetséges 48 pontból. Ez az érték alacsonynak tekinthető, hisz a megszerezhető érték egyharmadát sem éri el.

A pályán eltöltött évek és a kiégés egyes területei közötti kapcsolatot Spearman-féle rangkorreláció-elemzéssel vizsgáltuk. Az eredmények szerint a pályán eltöltött idő nem mutat szignifikáns kapcsolato a kiégés érzelmi $\left(\mathrm{r}_{(109)}=0,04 ; \mathrm{p}=0,72\right)$ és szociális $\left(r_{(109)}=-0,12 ; p=0,20\right)$ területeivel. Ugyanakkor a kiégés lelki területe és a pályán eltöltött idö között szignifikáns, negatív, gyenge kapcsolat van $\left(r_{(109)}=-0,24 ; p=0,01\right)$. Ez azt jelenti, hogy a régebben pályán lévők kevésbé mutatják a lelki kiégettség tüneteit, mint, akik kevesebb ideje vannak a pályán. 
Második elemzési szempontként a vegyes és tiszta (életkori homogén) csoportban végzett munka kiégéssel való összefüggését vizsgáltuk Az elvégzett Mann-Whitney próba eredménye alapján elmondható, hogy a két csoport között nincs szignifikáns különbség $(\mathrm{U}=1317,00, \mathrm{Z}=-0,06(\mathrm{p}=0,57)$.

\section{A kiégés fogékonyság és a pályával való elkötelezettség kapcsolata}

A kiégés mutató és a pályaelhagyással kapcsolatos gondolatok gyakorisága közötti összefüggést egyszempontú varianciaanalízissel vizsgáltuk. Az ANOVA eredménye szerint a két változó között szignifikáns kapcsolat van, mind a kiégés összpontszám $\left(\mathrm{F}_{(106)}=26,33 \mathrm{p}<0,001\right)$ mind az egyes alskálák esetében $\left(\mathrm{F}_{\text {érzelmi }}=22,82 \mathrm{p}<0,001\right.$; $\left.\mathrm{F}_{\text {lelki }}=23,86 \mathrm{p}<0,001 ; \mathrm{F}_{\text {szociális }}=6,02 \mathrm{p}<0,001\right)$. A kiégés magasabb értéke jellemző abban a csoportban, amelyik gyakran gondol a pályaelhagyásra.

A pálya újraválasztása a hivatással kapcsolatos elkötelezettségre utal, valamint az én-szerep illeszkedést is mutatja. A független mintás t-próba eredménye szerint, a kiégés összpontszám szignifikánsan magasabb volt azok körében, akik nem ezt a pályát választanák $\left(\mathrm{t}_{107)}=-3,44 \mathrm{p}<0,001\right)$ hasonlóképpen a lelki kiégés $\left(\mathrm{t}_{(107)}=-2,25 \mathrm{p}=0,026\right)$ és az érzelmi kiégés alsákák esetében $\left(\mathrm{t}_{(107)}=-4,09 \mathrm{p}<0,001\right)$. A szociális területen észlelt kiégés esetében nem kaptunk szignifikáns különbséget a két csoport értékei között $\left(\mathrm{t}_{(109)}=-0,86 \mathrm{p}<0,065\right)$. A kiégés pontszámokat és szórásukat az egyes csoportokban az 1. táblázat mutatja.

1. táblázat. A kiégés pontszámok átlagai és szórása a pálya újraválasztásának függvényében

\begin{tabular}{|l|c|c|c|}
\hline \multirow{2}{*}{ Lelki kiégés } & $\begin{array}{c}\text { Újra az óvónői } \\
\text { pályát választaná? }\end{array}$ & M & SD \\
\hline \multirow{2}{*}{ Érzelmi kiégés } & Igen & 4,11 & 2,234 \\
\cline { 2 - 4 } & Nem & 5,19 & 2,728 \\
\hline \multirow{2}{*}{ Szociális kiégés } & Igen & 4,98 & 2,657 \\
\cline { 2 - 4 } & Nem & 7,23 & 3,015 \\
\hline \multirow{2}{*}{ Kiégés összesített pontszám } & Igen & 2,39 & 2,571 \\
\cline { 2 - 4 } & Nem & 3,26 & 2,048 \\
\cline { 2 - 4 } & Igen & 11,48 & 5,722 \\
\hline
\end{tabular}

\section{Az óvodapedagógusi munka jellemzése a Super-féle munkaérték mentén}

A munkában megélt értékkörök rangsorának felállításhoz arra kértük, a vizsgálati személyeket, hogy jellemezzék jelenlegi munkahelyüket a Super kérdőív segítségével. A unkaértékek teljesülésének erősségét csökkenő sorrendben a 2. táblázat mutatja. 


\begin{tabular}{l|l|c|c|}
\hline \multicolumn{3}{|l}{ 2. táblázat. A jelenlegi munkahely jellemzése a Super-fél 15 értékkör mentén (N=112) } \\
\hline & & átlag & szórás \\
\cline { 2 - 4 } & altruizmus & 12,34 & 2,921 \\
\hline változatosság & 12,11 & 2,985 \\
\hline & társas kapcsolatok & 11,39 & 3,026 \\
\hline kreativítás & 11,13 & 3,308 \\
\hline fizikai környezet & 10,94 & 3,117 \\
\hline munkával kapcsolatos biztonság & 10,87 & 2,843 \\
\hline hierarchia & 10,54 & 3,487 \\
\hline önérvényesítés & 10,46 & 3,084 \\
\hline szellemi ösztönzés & 10,32 & 2,679 \\
\hline esztétikum & 10,28 & 3,026 \\
\hline munkateljesítmény & 10,08 & 2,665 \\
\hline presztízs & 9,80 & 2,995 \\
\hline függetlenség & 9,71 & 2,918 \\
\hline irányítás & 8,59 & 3,426 \\
\hline anyagiak & 6,85 & 2,935 \\
\hline
\end{tabular}

A táblázat adataiból látszik, hogy a legjellemzőbb munkaérték, amelyet megtapasztalnak a napi munka során az az altruizmus és a változatosság. A legkevésbé jellemző, hogy a munkájukat presztízst adónak élnék meg, függetlennek éreznék magukat, megélnék az irányítást. Az anyagi értékek teljesülése áll a rangsor utolsó helyén.

\section{A megélt munkaértékek és kiégés összefüggései}

A kutatás további kérdése volt, hogy a megtapasztalt munkaértékek hogyan kapcsolódnak a kiégéshez. Azaz melyek azok a munkaértékek, amelyek teljesülésének hiánya magasabb kiégettség pontszámmal jár együtt és fordítva.

A változók közötti együttjárásokat Spearman-féle rangkorrelációs eljárással elemeztük. Az aktuális munkahelyen megtapasztalt munkaértékek és a kiégés mértéke között közepesen erős negatív együttjárások figyelhetők meg (lásd 3. táblázat). Azaz, minél kevésbé teljesül az adott érték, annál magasabb a kiégés fogékonyság. 
Szabó Éva - Litke Márta - Jagodics Balázs: Az óvodapedagógusok kiégésének vizsgálata a munkaértékek tükrében

3. táblázat. A munkahelyen tapasztalt munkaértékek és a kiégés összesitett pontszáma közötti korrelációelemzés eredményei. (Az irányitás kivételével minden együttjárás szignifikáns, $p<0,001$ )

\begin{tabular}{|l|c|c|}
\hline \multicolumn{1}{|c|}{ Változó } & $\begin{array}{c}\text { Korrelációs együttható } \\
\text { (Spearman) }\end{array}$ & $\begin{array}{c}\text { Szignifikancia- } \\
\text { szint }\end{array}$ \\
\hline Szellemi ösztönzés & $-0,313$ & 0,001 \\
\hline Altruizmus & $-0,400$ & $<0,001$ \\
\hline Társas kapcsolatok & $-0,318$ & 0,001 \\
\hline Munkával kapcsolatos biztonság & $-0,403$ & $<0,001$ \\
\hline Anyagiak & $-0,303$ & 0,001 \\
\hline Önérvényesítés & $-0,606$ & $<0,001$ \\
\hline Változatosság & $-0,430$ & $<0,001$ \\
\hline Hierarchia & $-0,438$ & $<0,001$ \\
\hline Függetlenség & $-0,413$ & $<0,001$ \\
\hline Fizikai környezet & $-0,413$ & $<0,001$ \\
\hline Presztízs & $-0,428$ & $<0,001$ \\
\hline Munkateljesítmény & $-0,403$ & $<0,001$ \\
\hline Esztétikum & $-0,324$ & 0,001 \\
\hline Irányítás & $-0,143$ (n.sz.) & 0,138 (n.sz.) \\
\hline Kreativitás & $-0,483$ & $<0,001$ \\
\hline
\end{tabular}

Ahogy az a 3. táblázat adataiból is leolvasható, legerősebb együttjárást az önérvényesítés és a kreativitás értékek esetén kaptunk. Azaz, minél kevésbé érzi a munkavállaló, hogy szükség van a kreativitására, és érvényesítheti is saját ötleteit, annál valószínübb, hogy kiégettség jeleit mutatja.

\section{A kiégés értékét bejósló tényezők vizsgálata - elméleti modell}

Kutatásunk fő célkitűzése annak vizsgálata volt, hogy a munkaértékekkel kapcsolatos munkahelyi tapasztalatok hogyan kapcsolódnak a kiégés kialakulásához. A változók hatását Stepwise módszerrel végzett lineáris regresszióelemzés segítségével modelleztük. A modellben (1. ábra) függő változóként az összesített kiégés pontszámot használtuk, míg független változóként a munkaértékekre vonatkozó munkahelyi tapasztalatok szerepeltek.

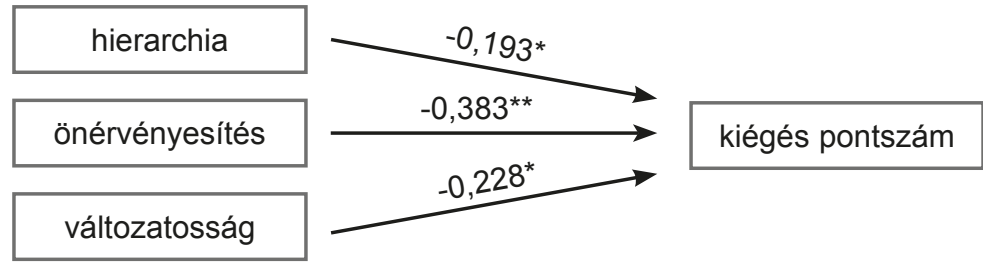

1. ábra. A kiégés pontszám és a munkaértékek közötti kapcsolatot leiró lineáris regressziós modell $(N=109 ; * p<0,05 ; * * p<0,001)$

A munkaértékek közül három változó (hierarchia, önérvényesítés és változatosság) mutatkozott szignifikáns hatásúnak a kiégés pontszámra $(\mathrm{F}(3,105)=25,500$; $\mathrm{p}<0,001)$. A három változó együttesen közel 40\%-ban magyarázza a kiégés pontszám 
varianciáját $\left(\mathrm{R}^{2}{ }_{\mathrm{adj}}=0,405\right)$. Az eredmények azt mutatják, hogy a kiégést legerősebben az önérvényesítés, a munkában megélt önmegvalósítás hiánya jósolja be. Ezt követi a változatosság hiánya és végül meghatározó szerepet játszik a hierarchia értékkör is, amely az igazságos ellenőrzés alatt végzett munkára, illetve a vezetővel kialakított viszonyra utal.

\section{Következtetések, megvitatás}

Kutatásunk középpontjában a segítő szakmák közül az óvodapedagógusok csoportja állt. Korábbi kutatások elsősorban a tanári kiégésre koncentráltak. Jelen vizsgálat ebből a szempontból úttörő jellegünek mondható. A kutatás másik újdonsága, hogy a munkahelyi jellemzőket most nem a szokásos stressztényezőkön (Maslach, 1982) vagy erőforrás-követelmény elemeken (Szabó és Jagodics, 2016) és nem is a társas kontextus (Zapf, 2002) leírásán keresztül közelítettük meg. Jelen vizsgálatban a munkaértékek megélt minőségét kívántuk megragadni, feltételezve, hogy ezek befolyásolják a kiégés mértékét.

A kiégéssel kapcsolatos eredmények alapján azt mondhatjuk, hogy az általunk vizsgált csoport a korábbi kutatásokhoz hasonlóan kifejezetten alacsony értéket mutat. Ez azonban ellentmond a pedagógusokra vonatkozó nemzetközi kutatások eredményeinek (Barth, 1990) éppúgy, mint a hétköznapi tapasztalatoknak. Ugyanakkor jelentősen egybehangzik a hazai kutatásokban talált adatokkal (Petróczi, 1999; Paksi és mtsai, 2015; Szabó és Jagodics, 2016). Az alacsony kiégésmutatókat magyarázhatjuk a társas kívánatosságnak való megfeleléssel (Ashton, Buhr és Crocker, 1984), de akár azzal is, hogy az önkéntes vizsgálatba valószínűbben vesznek részt olyan pedagógusok, akik kevésbé kiégettek, mint akik erősen érintettek ezzel a problémával.

Módszertani szempontból is újnak mondható feltevésünk, miszerint a munkában megélt értékek, mint az elégedettség tényezői negatív kapcsolatban állnak a kiégéssel. A Super-féle munkaérték kérdőívvel végzett kutatásunk eredménye azt mutatja, hogy a mintában szereplő óvodapedagógusok leginkább az altruizmus, a változatosság és a társas kapcsolatok értékeit érzik kiteljesedettnek a munkában. Legkevésbé pedig a függetlenség, az anyagiak és az irányítás értékei elégítettek ki számukra. Ezek az eredmények reálisan leképezik az óvodapedagógusi munka jellegzetességét, és társadalmi helyzetét is. A gyerekekkel való foglalkozás alapvetően az altruizmusra épülö és rendkívül változatos tevékenység, amelyet általában kisebb szakmai csoportokban, teamekben végeznek. Az óvodák az esetek

A vizsgált csoportban a korábbi hazai kutatások eredményéhez hasonlóan (Gáspár és mtsai, 2006) azt találtuk, hogy a pályán eltöltött idó és a kiégés negatív kapcsolatban áll a lelki kimerüléssel. Eszerint azok veszélyeztetettebbek, akik még a pálya elején tartanak.

Ezt az eredményt részben magyarázhatja a pályával és a munkával való elkötelezettség és a kiégés közötti kapcsolat. Azt találtuk, hogy akik elkötelezettebbek a hivatással, azok kevésbé kiégettek. Vélhetốen a pályával való mélyebb elkötelezôdés hosszabb idó alatt alakul ki, és ez egyfajta védófaktorként múködhet a kiégéssel szemben. A pályájuk elején tartókban ez a meggyózôdés még nem olyan erôs, talán éppen formálódik. 
legnagyobb részében viszonylag kis létszámú intézmények, ahol a pedagógusok jól ismerik és valószínüleg kölcsönösen segítik egymás munkáját. Ugyanakkor az is egyértelmü, hogy ez a szakma jelentősen alulfizetett a társadalomban, valamint az utóbbi évtizedek különböző oktatáspolitikai reformtörekvései miatt egyre kevesebb teret ad a pedagógiai függetlenségnek és az irányításnak is.

A kiégést azonban nem pontosan ugyanezek az értékkörök befolyásolják leginkább. A lineáris regressziós elemzésben sem az alul fizetettség, sem a presztízs, sem a függetlenség nem szerepelt, mint szignifikáns hatású változó. A vizsgált csoportban a kiégés mértékét leginkább a megértő és demokratikus vezető hiánya, a csökkent önmegvalósítás élmény és a változatosság értékének alacsony megjelenése magyarázza. A modell azt sugallja, hogy a kiégés visszafordítása vagy megelőzése érdekében a vezetők hozzáállásán lenne érdemes elsősorban változtatni. Fontos lenne javítani az értékelés-ellenőrzés módján, és nagyobb mértékben bevonni a pedagógusokat is a munkával kapcsolatos döntésekbe. Ezen kívül olyan feltételeket kéne teremteni, amely több lehetőséget kínál az óvodapedagógusoknak arra, hogy megvalósítsák elképzeléseiket, és önmagukat a munkájuk során. A változatosság hiánya vélhetően a rutinszerüvé váló munkavégzésből adódik, amely talán abból is következhet, hogy a feladatokat nem maguk a pedagógusok alakítják ki, hanem azokat elöírják számukra. Fontos azonban hangsúlyozni, hogy jelen kutatásba az óvónők egy szük csoportja vett részt. Jelen vizsgálat nem tükrözi a hazai óvodapedagógusok helyzetét, de rámutat arra, hogy az általunk kidolgozott eljárás alkalmas lenne arra, hogy rámutasson a fontos munkaértékekre, melyek teljesülését jobb munkaszervezéssel, kisebb-nagyobb szervezeti változásokkal facilitálni lehetne, ami hozzájárulhatna a kiégés csökkenéséhez. Ahhoz, hogy még pontosabb képet kapjunk a munkaértékek kiégésben betöltött szerepéről nemcsak a munkaértékek megvalósulását kellene feltárni, hanem az elvárt és megvalósult munkaértékek közötti eltérést is, amelyet további munkánk fö irányvonalának tekintünk.

\section{Felhasznált irodalom:}

Ashton, P., Buhr, D., \& Crocker, L. (1984). Teachers' sense of efficacy: A self- or norm-referenced construct? Florida Journal of Educational Research, 26(1), 29-41.

Ádám Sz, Győrffy Zs. \& Csoboth Cs. (2006). Kiégés (burnout) szindróma az orvosi hivatásban. Hippocrates, 8(2): 113-117.

Ádám Sz, Győrffy Zs. \& Susánszky É. (2008) Physician burnout in Hungary. Journal of Health Psychology, 13(7): 847-856. DOI: 10.1177/1359105308095055

Ádám Sz, Torzsa P, Győrffy Zs, Vörös K. \& Kalabay L. (2009) Gyakori a magas fokú kiégés a háziorvosok és a háziorvosi rezidensek körében. Orv Hetilap, 150(7): 317-323.

Bagdy E. (1994): Pedagógusszerepben. A szakmai önazonosság kialakulása, pályaszocializáció. In: Jávorka H., Liber E., Mentlerné Ferenczi T. és Zsokai G. (szerk) Tanári életkérdések. Budapest: Raabe.

Barth, A.R. (1990). Burnout bei Lehrern: eine empirische Untersuchung. (Dissertation) Nünberg: Universitat Erlangen. In: Horváth Sz. (2012): Pedagógus burnout prevenciójának lehetőségei. Mozgás, környezet, egészség, International Research Institute sro, Komárom, 155-173.

Bognár T., Kolosai N., Hegedűs K. \& Pilling J. (2001) „Kellene, aki megfogná a haldokló kezét” Orvosokkal készült mélyinterjúk elemzése a haldoklógondozás nehézségeiről. LAM, 11(2):154-162.

Bracci, E. (2009) Autonomy, responsibility and accountability in the Italien school system. Critical Perspectives on Accounting 20(3), 293-312. DOI: 10.1016/j.cpa.2008.09.001

Candová, A. (2005). Determinanten de beruflichen Belastung bei jungen Lehrerinnen und Lehrer Eine Langschnittstudie (Doktori értekezés). Friedrich-Alexander-Universitat, Nürnberg.

Csirszka J. (1966): Pályalélektan. Gondolat Kiadó, Budapest

Demerouti, E., Bakker, A. B., Nachreiner, F., Schaufeki, W.B. (2001) The Job Demands-Resources Model of Burnout. Journal of Applied Psychology, 86(3), 499-512.

Duró L, Kékes SzM., Pigler L. (2005) A pedagógiai gyakorlat pszichológiája. BBS-INFO Kiadó, 5-41. 
Fekete S. (1991): Segítő foglalkozások kockázata. Helfer szindróma és burnout jelenség. In: Psychiátria Hungarica, VI. I. 17-29. Budapest

Fernet, C., Guay, F, Senécal, C., és Austin, S. (2012) Predicting intraindividual changes in teacher burnout: The role of perceived school environment and motivational factors. Teaching and Teacher Education, 28. 514-525. DOI: 10.1016/j.tate.2011.11.013

Fónai M., Zolnai E., Kiss J. (2005): A hallgatók munkaérték preferenciái, In: Szerk.: Pusztai Gabriella: Régió és oktatás európai dimenzióban. Debrecen: Doktoranduszok Kiss Árpád Közhasznú Egyesülete. pp. 190-205.

Freudenberger, H. J. (1974): Staff Burn-Out. Journal of Social Issues. 30(1): 159-165. DOI: 10.1111/ j.1540-4560.1974.tb00706.x

Gáspár M., Holecz A., Kiss J., Kovács J., Örkényi Á. és Simon K. (2006) A személyiség belső feltételeinek és stabilitásának alakulása a pályaszocializáció függvényében. OTKA pályázat, Budapest.

Gáspár M. (2008) A személyiség belső feltételeinek és stabilitásának alakulása a pályaszocializáció függvényében. OTKA-pályázat zárójelentése. Budapest, OTKA.

Győrffy Zs, Ádám Sz. (2004) Az egészségi állapot, a munkastressz és a kiégés alakulása az orvosi hivatásban. Szociol Szle, 3: 107-127.

Hakanen, J.J., Bakker, A. B. és Schaufeli, W.B. (2006): Burnout and work engagement among teachers. Journal of School Psychology, 43(6): 495-513. DOI: 10.1016/j.jsp.2005.11.001

Hare, J., Pratt, C. C., és Andrews, D. (1988) Predictors of burnout in professional and paraprofessional nurses working in hospitals and nursing homes. International Journal of Nursing Studies, 25(2), 105-115. DOI: 10.1016/0020-7489(88)90078-8

Hegedűs K. (2000) A haldokló betegeket kísérő személyzet mentálhigiénéje, A kiégés és a pszichés terhek csökkentésének lehetőségei. LAM, 10(5): 448-452.

Hegedűs K, Riskó Á. \& Mészáros E. (2004) A súlyos betegekkel foglalkozó egészségügyi dolgozók testi és lelki állapota. LAM, 14(11): 786-793.

Hézser G. (1996): Miért? Rendszerszemlélet és lelkigondozói gyakorlat, Pasztorálpszichológiai tanulmányok. Budapest, Kálvin Kiadó

Holecz A. (2015). A pedagógusok pszichés fejlődését segítő képzési feladatok és lehetőségek a tanárképzés és továbbképzés endszerében. In: Tanulmányok a pedagógusképzés 21. századi fejlesztéséhez. Nyugat-magyarországi Egyetem Regionális Pedagógiai Szolgáltató és Kutató Központ, Szombathely. 145-164.

Jagodics B. és Szabó É. (2016). Erőforrások és követelmények, A tanári kiégés munkahelyi tényezőinek komplex vizsgálata. Iskolakultúra, 26(11): 3-15. DOI: 10.17543/iskkult.2016.11.3
Kocsis M. (2003). A tanárképzés megítélése. Iskolakultúra-könyvek, 18. Pécs: Iskolakultúra.

Kollár Cs., (2014): A munkahelyi kiégés (burnout szindróma) elméleti megközelítése, kutatási irányai és közgazdaságtudományi aspektusa. Fluentum 1(3). Letöltve: 2018. március 13. http://epa.oszk. hu/02500/02560/00003/pdf/

Koruklu, N., Feyzioglu, B., Özenoglu-Kiremit, H., \& Aladag, E. (2012). Teachers' Burnout Levels in terms of Some Variables. Educational Sciences: Theory \& Practice, 12(3) 1823-1830.

Kovács M. (2006): A kiégés jelensége a kutatási eredmények tükrében. LAM Orvoslás és Társadalom, 16(11): 981-987.

Kyriacau, C. (2001): Teacher stress: directions for future research. Educational Review, 53(1): 17-35. DOI: 10.1080/00131910124115. Idézi: Torma B. (2013) Pedagóguspályák. Utak és lehetőségek a kiégés és szakmai kiteljesedés között. Alkalmazott Pszichológia 13(3): 7-25.

Lackritz, J.R. (2004) Exploring burnout among university faculty: incidence, performance and demographic issues. Teaching and Teacher Education, 20(7): 713-729. DOI: 10.1016/j.tate.2004.07.002

Maslach C. (1982): The effects of burnout. In: Burnout: The cost of caring. Prentice-Hall.,Engelwood Cliffs. NJ. pp. 71-85.

Maslach C., Jackson S. E. (1981): The measurement of experienced burnout. Journal of Organizational Behavior 2(2): 99-113. DOI: 10.1002/job.4030020205

Maslach C., Schaufeli, W. (1993): Historical and conceptual development of burnout. In: Schaufeli, W., Maslach C., Marek T., Editors, Professional burnout: reccent developments in theory and research. Taylor and Francis, Washington DC. pp. 1-16.

Maslach C, Schaufeli WB, Leiter MP. (2001) Job Burnout. Annu Review of Psychology, 52(1): $397-$ 422. DOI: 10.1146/annurev.psych.52.1.397

Ónody S, Bálintné dr. Dancsó M.( 2001). Segítő kapcsolat, segitö beszélgetés. „Egy kapcsolat, mely érthetővé tehetö". Officina Press Kft., Szeged, 103-113.

Paksi B., Veroszta ZS., Schmidt A., Magi A., Vörös A., Endrődi-Kovácsi V., Felvinczi K. (2015). Pedagógus-Pálya-Motiváció-Egy kutatás eredményei. Oktatási Hivatal, Budapest.

Pálfi F. (2003). Szolgálat, önfeláldozás, hivatás? - A kiégés veszélyei ápolók körében. Növér, 16(6): 3-9.

Petróczi E.(1999).Akiégés jelensége pedagógusoknál. Magyar Pszichológiai Szemle, 54 (3), 127-139.

Pikó B. (2001). A nővéri munka magatartástudományi vizsgálata. Pszichoszomatikus tünetek, munkahelyi stressz, társas támogatás, $L A M, 11(4)$ : 318-325.

Pikó B. (2006). Burnout, role conflict, job satisfaction and psychosocial health among Hungarian health care staff: A questionnaire survey. International Journal 
of Nursing Studies, 43(3): 311-318. DOI: 10.1016/j. ijnurstu.2005.05.003

Pines A., Maslach C. (1978). Characteristics of Staff Burnout in Mental Health Settings. Hospital \& Community Psychiatry, 29(4): 23-237. DOI: 10.1176/ ps.29.4.233

Pruyser,P, (1984). Existentail impact of professional exposure to life-threatening or terminal illness. Bulletin of the Menninger Clinic, 48, 357-367.

Ritoók P. (1986). Személyiségfejlesztés és pályaválasztás. Tankönyvkiadó, Budapest.

Rókusfalvy Pál (1969). Pályaválasztás, pályaválasztási érettség. Budapest, Tankönyvkiadó
Simbula, S., Panari C., Guglielmi, D., \& Fraccaroli, F. (2012). Teachers' Well-being and Effectiveness: The Role of the Interplay between Job Demands and Job Resources. Procedia - Social and Behavioral Sciences, 69: 729-738. DOI: 10.1016/j.sbspro.2012.11.467

Szicsek M. (2004) Kiégés és pszichológiai immunkompetencia összefüggései az ápolói munkában. Kharón, Thanatológiai Szemle, 8(1-2): 88-131.

Völgyesi P. (1976): A pályaválasztási döntés elökészitése. Tankönyvkiadó, Budapest.

Zapf D. (2002): Emotion work and psychological well-being. A review of the literature and some conceptual considerations. Human Resource Management Review, 12(2): 237-268. DOI: 10.1016/s10534822(02)00048-7

\title{
Absztrakt
}

A pedagógus pálya egyik gyakori szakmai jellegzetessége a kiégés szindróma megjelenése. Feltehetően nincs ez másképp az óvodapedagógusok körében sem, ugyanakkor ezt a pedagóguscsoportot a korábbiakban nem vizsgálták ebből a szempontból. Kutatásunk célja az óvodapedagógusok kiégésre való fogékonyságának vizsgálata. Annak feltárása, hogy a pályán eltöltött idő, munkavégzés körülményei és az egyes munkaérték jellemzők hogyan kapcsolódnak a kiégéshez. A vizsgálatban 109 óvodapedagógus vett részt. A pedagógusok kiégés fogékonyságát a Szabó és Jagodics (2016) kérdőívével mértük, a munkakörülményekre a Super-féle munkaérték kérdőívvel kérdeztünk rá, illetve felvettünk néhány demográfiai és pályamotivációs adatot is. Az eredmények szerint a pályán eltöltött idő fordított kapcsolatot mutat a kiégéssel, ami független attól, hogy az óvodapedagógus homogén vagy vegyes életkori csoportokkal dolgozik. A munkaértékek többségének megvalósulása negatív korrelációt mutat a kiégés fogékonysággal. A kiégés fogékonyságot legnagyobb mértékben az egyértelmü hierarchia hiánya, az önmegvalósítás lehetőségének alacsony szintje és a változatos munkahelyi feladatok csökkent mértéke jósolták be. Kutatásunk legfőbb eredménye, hogy a munkaértékeknek jelentős kapcsolata van a kiégéssel, így ennek vizsgálata alkalmas módszernek látszik az óvodákban és az iskolákban dolgozó pedagógusok kiégésének feltárásában és megelőzésében.

\begin{abstract}
The teacher profession is often associated with high rates of burnout. There are less scientific research regarding kindergarden teachers, but presumably their situation is similair to the school teachers. The goal of our study is the symptoms of burnout among kindergarden teachers. We analysed the relationship between professional experience (in years), work environment, individual values and burnout. 109 kindergarden teachers participated in the study. We used the Teacher Burnout Scale (Szabó \& Jagodics, 2016), the Super Value Questionnaire and questions to measure the demographic background and the professional motivation. The results claim that work experience is negatively associated with burnout, which is not related to the age group of the children (homogeneous or heterogenous). The presence of workplace values are negatively related to burnout scores, which is mostly predicted by the absence of clear hierarchy, the low level of possible self-actualization and the monotonous workplace tasks. The main result of our study is that we found relationship between burnout and workplace values, therefore its research could reveal important findings regarding burnout syndrome at both kindergarden and school teachers.
\end{abstract}

